\title{
Cases with Hyperplasia and Neoplasia in Endocrine Glands in Dogs
}

\author{
Adrian Florin GAL*1, Viorel MICLĂUȘ ${ }^{1}$, Marian TAULESCU ${ }^{1}$, Flaviu TĂBĂRAN ${ }^{1}$, Andras NAGY ${ }^{1}$, Cosmina \\ BOUARI $^{1}$, Raluca VIDRIGHINESCU ${ }^{1}$, Roxana CORA ${ }^{1}$, Cornel CĂTOI ${ }^{1}$
}

${ }^{1}$ Faculty of Veterinary Medicine, University of Agricultural Sciences and Veterinary Medicine, 3-5

Mãnãștur Street, 3400 Cluj-Napoca, ROMANIA

Corresponding author, e-mail: adrian.gal@usamvcluj.ro

Bulletin UASVM Veterinary Medicine 71(2) / 2014,

Print ISSN 1843-5270; Electronic ISSN 1843-5378

DOI:10.15835/buasvmcn-vm: 10357

\begin{abstract}
Endocrine tumors are found sporadically in both humans and animals. They originate from endocrine organs and diffuse neuroendocrine system. The present paper describes cases of tumors/hyperplasia in various endocrine glands in dogs. The material included canine corpses and biopsies brought for necropsy and/or histological examination, which occurred in the Department of Pathological Anatomy (Faculty of Veterinary Medicine, ClujNapoca, Romania). Tissue samples were collected, fixed in $10 \%$ buffered formalin and routinely processed for histology. In all cases the canine endocrine tumors were diagnosed only after necropsy. In some cases simple endocrine neoplasms were identified, while in other cases multiple endocrine tumors were observed. Testicular Sertoli cell tumors and/or Leydig cell tumor can be considered endocrine tumors since (in some cases) the clinical manifestations are relatively sharp. In one case bearing Sertoli cell tumor we observed the feminization syndrome. Concerning adrenal glands, cortical adenoma, carcinoma and medullar pheocromocytoma were diagnosed in three dogs respectively. Thyroidal tumors were either with the proliferation of follicular cells or with the involvement of parafollicular cells. In one dog showing a thyroidal tumor and bilateral hyperplasia of the parathyroid glands, multiple endocrine lesions were also observed, in a picture of Multiple Endocrine Neoplasia (MEN) syndrome. Similar condition was demonstrated in two other dogs with concomitant testicular and adrenal tumors. This is the first description of this syndrome in dogs in Romania. Endocrine tumors are extremely rare in animals. In dogs suspected to bear endocrine tumors, it is essential to investigate all endocrine glands to determine if the subject presents MEN or MEN-like syndrome.
\end{abstract}

Keywords: dog, endocrine tumor, MEN-syndrome.

\section{INTRODUCTION}

Endocrine tumors are found sporadically in both humans and animals. They have the origin in endocrine organs or in the diffuse neuroendocrine system (APUD - Amine Precursor Uptake Decarboxylase). Endocrine tumors can be classified according to their behavior and induced dysfunctions in: hyperplastic lesions, benign or malignant tumors. Endocrine glands hyperplasia determines an aberrant secretion of hormones and is grossly associated with increased volume of the endocrine gland affected. Endocrine adenomas and carcinomas are often similar histologically, which makes histological diagnosis to be a challenge (Baba and Catoi, 2007).
The hypertrophy of the endocrine gland, as a consequence of tumor extension, often leads to the compression atrophy of nearby organs. Malignant tumors cause destruction of both the affected gland and its adjacent tissue, as a consequence of the invasion (Withrow et al., 2012).

Primary endocrine neoplasms may occur as single or multiple entities. The latter can cause a syndrome called Multiple Endocrine Neoplasia (MEN) syndrome if tumors occur in the following organs: pancreas, thyroid, parathyroid, adrenal and pituitary glands. MEN has been described in a very small number of species and cases: in horse (De Cock, 1999), dog (Brever et al., 1991; Walker et al., 2000), cat and ox (Sponenberg, 1983). They 
are characterized by the presence of at least two endocrine tumors (including hyperplastic lesions) in the same subject. Genetic substrate (i.e., autosomal dominant gene) has been suggested by some authors (Phay et al., 2000; Thakker, 2000).

Our paper presents cases with tumors/hyperplastic lesions in various endocrine glands in dogs that have been diagnosed in the Department of Pathology (Faculty of Veterinary Medicine ClujNapoca, Romania). For each case, a description concerning the case history, necropsy and histological findings encountered is given.

\section{MATERIALS AND METHODS}

The material included dog corpses and biopsies submitted to necropsy and/or histological examination in the Department of Pathological Anatomy (Faculty of Veterinary Medicine, Cluj-Napoca, Romania). The following data were recorded for each case: age, breed, dog history, necropsy findings (for some cases), tumor(s) site including gross findings (i.e., the tumor size, consistency, appearance of the tumor in cross section). Neoplastic samples were collected, fixed in 10\% buffered formalin and routinely processed for histology. From paraffin blocks, 5 micron thick sections were obtained and stained with Hematoxylin-eosin (HE). Histologic examination was performed using the Olympus BX51 microscope connected to a digital camera (Olympus DP-25).

\section{RESULTS AND DISCUSSION}

The results assessed in the cases examined are shown in Table 1.

Research conducted in the Department of Pathology and Necropsy (FVM Cluj-Napoca) shows that endocrine tumors in dogs are rare entities and often diagnosed only after necropsy. Investigated cases showed simple and multiple endocrine lesions (i.e., tumors and/or hyperplasia) in the following organs: testis, thyroid, parathyroid, and adrenal glands.

Testicular tumors (e.g., Sertoli cells tumor, Leydig cells tumor) were the most common endocrine tumors diagnosed (four cases; Figs. 1-3). Frequently, the clinical manifestations associated with these tumors are relatively clear and can raise the suspicion of tumor at this level. Sertoli cell tumors are endocrine tumors since the estrogen hypersecretion regularly occurs. As noted in the cases 1,3 , and 4, they were associated with the feminization syndrome suggested by the prepuce swelling, reduced hairiness, skin hyperpigmentation, skin thinning, etc. These clinical signs can be helpful for a veterinary clinician in the diagnosis of Sertoli cell tumor. Furthermore, such tumors can be associated with a myelodysplastic syndrome that predispose to infection. The paraneoplastic syndrome, manifested by the feminization in males, was suggested by other reports (Brodey et al., 1958; Lipowitz et al., 1973; Reif et al., 1979; Weaver, 1983).

Sertoli cells tumor is the most common neoplasm of the testis (about $90 \%$ of all gynecological malignancies in male; Cotchin, 1960; von Bomhard et al., 1978, Liao et al., 2009). Risk factors incriminated for dogs: cryptorchidism, age, breed and various carcinogens (Hayes, 1990; Hayes et al., 1995). There seems to be a link between cryptorchidism and the emergence of Sertoli cells tumor and seminoma. Apparently, the cryptorchidism doesn't interfere with the occurrence of interstitial Leydig cell tumors (Reif et al., 1969; Reif et al., 1979; Liao et al., 2009).

Another endocrine lesion that may occur in testis is the hyperplasia/neoplasia of Leydig cells. They may be associated with the hypersecretion of testosterone. The hyperplasia of the Leydig gland may progress as a solitary neoplastic or hyperplastic lesion (case 2) or may be associated with other testicular tumors (case 4, Fig. 3).

Some other two dogs had hyperplastic lesions (Cases 5 and 6; Figs. 4, 6, 7) in the adrenal gland. In one dog was diagnosed an adrenocortical adenoma (Case 6; Fig. 6, 7), whereas the other one presented an adrenocortical malignant tumor (Case 5; Fig. 4). Depending on the affected portion, the adrenal gland tumors may be associated with different clinical manifestations. However, in the cases studied, such manifestations were absent and the diagnosis was established after necropsy (incidental finding of adrenal gland lesions in both dogs). Adrenal adenomas are four times more common than carcinomas and are usually smaller than two $\mathrm{cm}$ comparing to carcinomas (Labelle et al., 2004; Feldman et al., 2004). About 50\% of all adrenocortical carcinomas metastasize in various organs (e.g., the lung, kidney, ovary, etc.; Labelle, 2004). Functional adrenocortical tumors are very common. They are able to elaborate several hormones, such as: androsterone, proges- 
Tab. 1. General description of the investigated dogs.

\begin{tabular}{|c|c|c|c|c|c|c|c|}
\hline No. & $\begin{array}{l}\text { Dog } \\
\text { Sex }\end{array}$ & $\begin{array}{c}\text { Age } \\
\text { (years) }\end{array}$ & Breed & $\begin{array}{l}\text { Castra- } \\
\text { tion }\end{array}$ & Tumor location & Tumor size & Histological diagnosis \\
\hline \multirow[t]{2}{*}{1.} & \multirow[t]{2}{*}{ Male } & \multirow[t]{2}{*}{10} & \multirow{2}{*}{$\begin{array}{l}\text { German } \\
\text { Shepherd }\end{array}$} & \multirow[t]{2}{*}{ No } & -left testis & $-7,5 / 6 \mathrm{~cm}$ & $\begin{array}{l}\text {-Intratubular testicular } \\
\text { Sertoli cell tumor }\end{array}$ \\
\hline & & & & & -skin tumor & $-2 / 2,5 \mathrm{~cm}$ & -Eccrine gland adenoma \\
\hline 2. & Male & 10 & Rottweiler & No & -left testis & $-6,5 / 6 \mathrm{~cm}$ & -Angiomatoid Leydig cell tumor \\
\hline 3. & Male & 10 & Canish & No & $\begin{array}{l}\text {-right testis (retained } \\
\text { testis - unilateral } \\
\text { cryptorchidism) }\end{array}$ & $-3,4 \mathrm{~cm}$ & $\begin{array}{l}\text {-Invasive testicular } \\
\text { Sertoli cell tumor }\end{array}$ \\
\hline \multirow{2}{*}{4.} & \multirow{2}{*}{ Male } & \multirow{2}{*}{9} & \multirow{2}{*}{ Canish } & \multirow{2}{*}{ No } & $\begin{array}{l}\text {-right testis (bilateral } \\
\text { cryptorchidism) }\end{array}$ & $-6 \mathrm{~cm}$ & \multirow{2}{*}{$\begin{array}{l}\text {-In the both testes: } \\
\text { Intralobular Sertoli cell } \\
\text { tumor, diffuse seminoma } \\
\text { (multifocal), and interstitial } \\
\text { Leydig gland hyperplasia }\end{array}$} \\
\hline & & & & & $\begin{array}{l}\text {-left testis (bilateral } \\
\text { cryptorchidism) }\end{array}$ & $-5,5 \mathrm{~cm}$ & \\
\hline 5. & Female & 12 & Stray dog & No & -adrenal gland & $-2 / 3 \mathrm{~cm}$ & - Adrenocortical carcinoma \\
\hline 6. & Male & 12 & $\begin{array}{l}\text { Pitbull } \\
\text { Terrier }\end{array}$ & No & -left adrenal gland & $-3 / 2,5 \mathrm{~cm}$ & $\begin{array}{l}\text {-Pheochromocytoma } \\
\text { (adrenal medula) } \\
\text {-Adrenocortical adenoma } \\
\text { (proliferation of the both } \\
\text { zona glomerulosa and } \\
\text { zona fasciculata) }\end{array}$ \\
\hline 7. & Male & 11 & $\begin{array}{l}\text { American } \\
\text { Stafford- } \\
\text { shire Terrier }\end{array}$ & Yes & -thyroid gland & $-8 / 5 \mathrm{~cm}$ & -Medullary thyroid carcinoma \\
\hline \multirow{4}{*}{8.} & \multirow{4}{*}{ Male } & \multirow{4}{*}{10} & \multirow{4}{*}{ Canish } & \multirow{4}{*}{ No } & -right thyroid gland & $-3,5 / 3 \mathrm{~cm}$ & $\begin{array}{l}\text {-Follicular adenoma of } \\
\text { the thyroid gland }\end{array}$ \\
\hline & & & & & -right parathyroid glands & $-0,5 \mathrm{~cm}$ & $\begin{array}{l}\text {-Parathyroid gland hyperplasia } \\
\text { (with metastatic mineralization } \\
\text { in other tissues) }\end{array}$ \\
\hline & & & & & -left thyroid gland & $\begin{array}{c}-4,3 / 3,2 \\
\mathrm{~cm}\end{array}$ & $\begin{array}{l}\text {-Compact follicular carcinoma } \\
\text { of the thyroid gland }\end{array}$ \\
\hline & & & & & -left parathyroid glands & $0,5 \mathrm{~cm}$ & $\begin{array}{l}\text {-Parathyroid gland hyperplasia } \\
\text { (with metastatic mineralization } \\
\text { in other tissues) }\end{array}$ \\
\hline
\end{tabular}

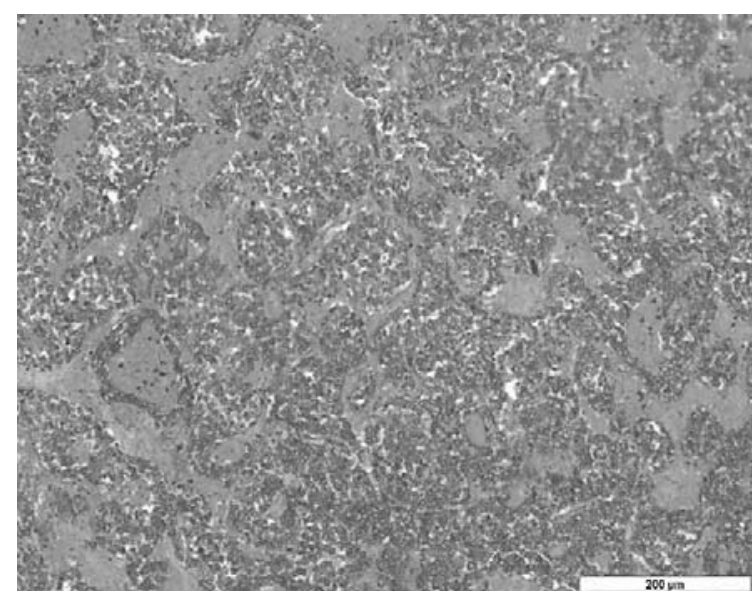

Fig 1. Angiomatoid Leydig cell tumor (case 2) - large vascular spaces; HE stain.

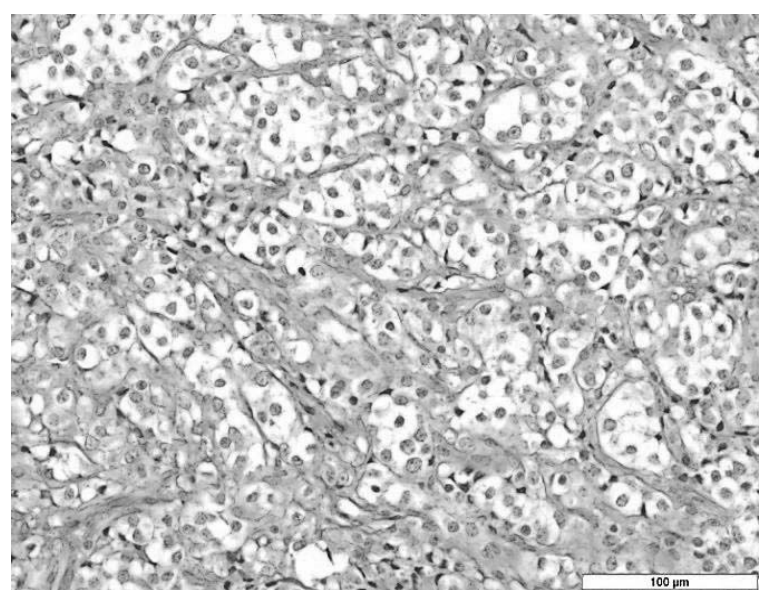

Fig 2. Invasive Sertoli cell tumor (case 3) - foamy aspect of the tumoral cells; HE stain. 


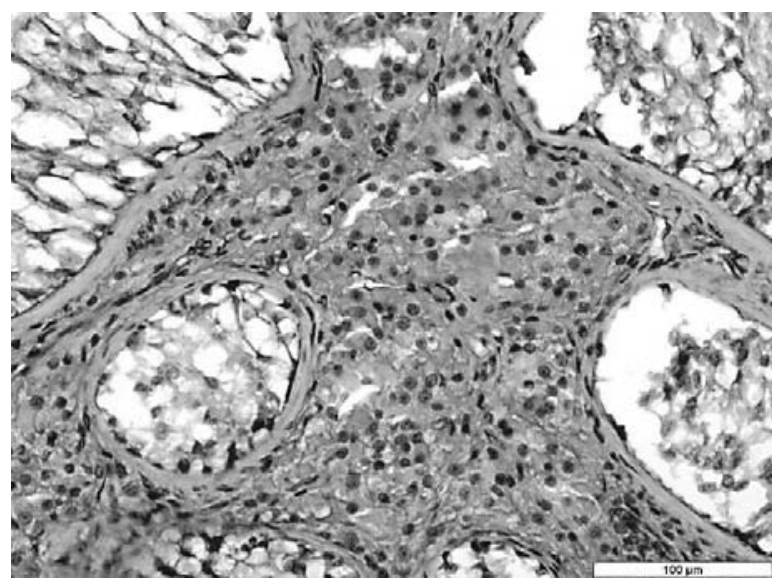

Fig. 3. Sertoli cell tumor (right testis) - interstitial Leydig cell hyperplasia (case 4); HE stain.

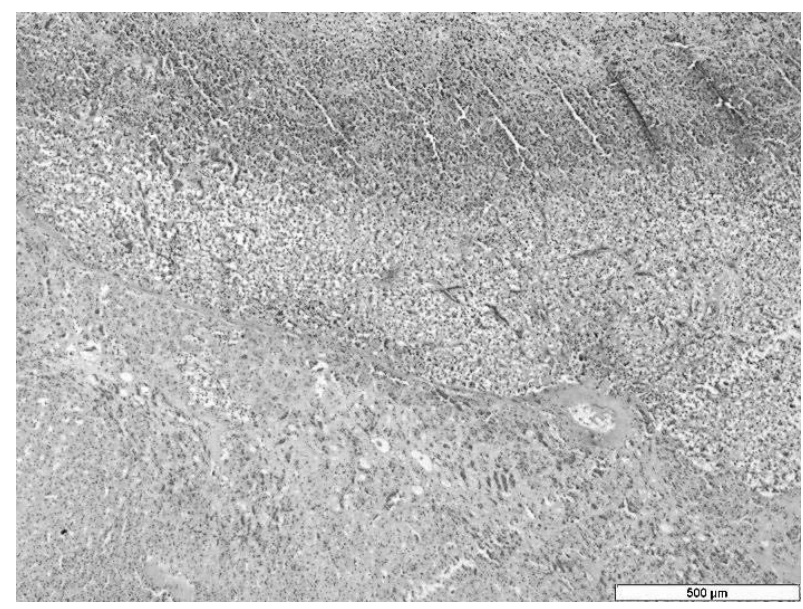

Fig. 5. Pheochromocytoma (adrenal medulla; case 6) - tumoral cell mass - accolade; HE stain.

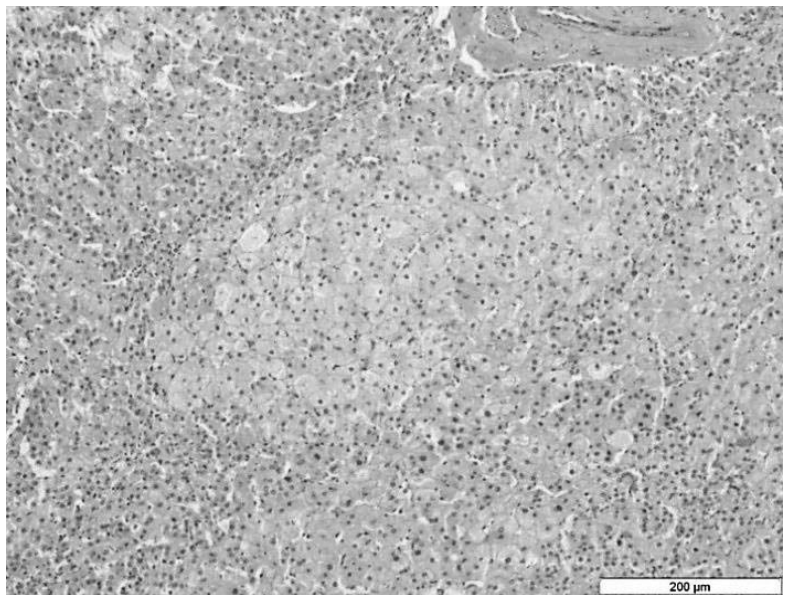

Fig. 7. Adrenocortical adenoma (case 6) nodular hyperplasia of sponge cells from zona fasciculata; HE stain.

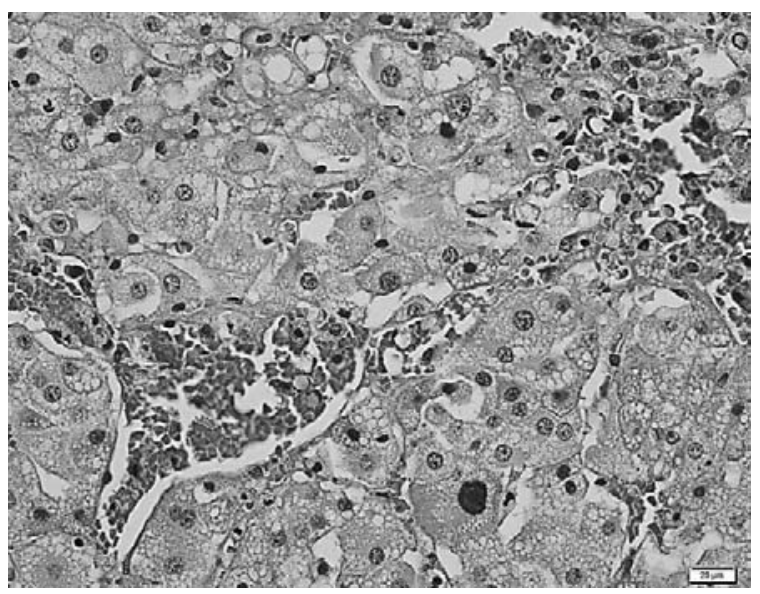

Fig. 4. Adrenocortical carcinoma (case 5) - neoplastic cells set in short cords/nests; macronuclei; HE stain.

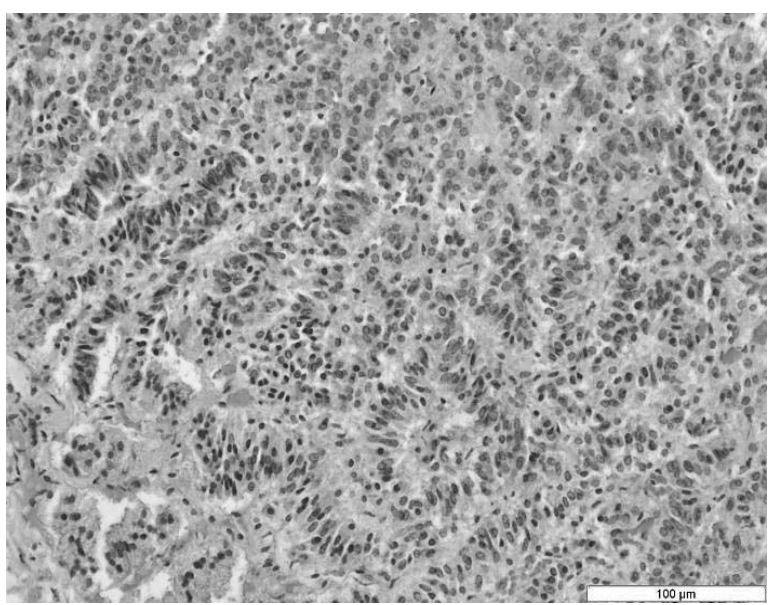

Fig. 6. Adrenocortical adenoma (case 6)

- extension of zona gromerulosa in zona fasciculata; HE stain.

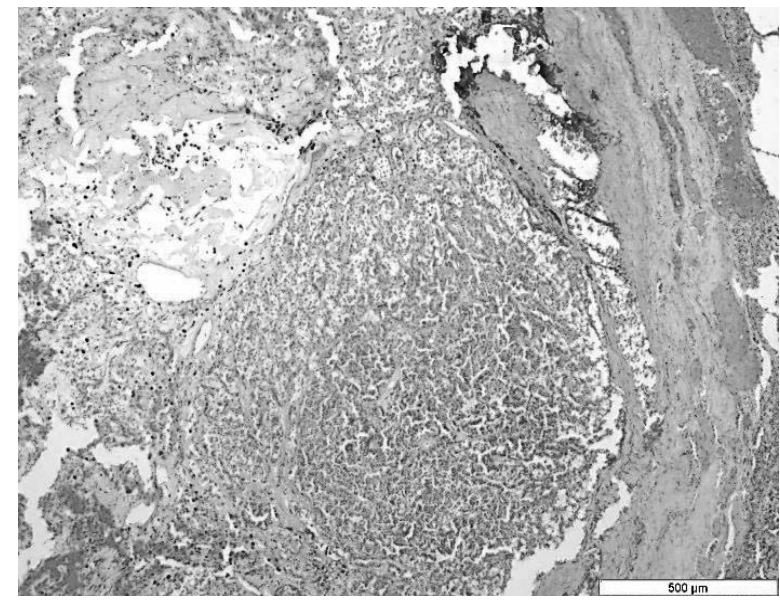

Fig. 8. Thyroidal carcinoma (left thyroid) haemorrhagic and necrotic microfoci in the tumoral mass (case 8); HE stain. 
terone, testosterone, estradiol and in rare cases cortisol or aldosterone (Conn's syndrome). In cats, aldosterone-secreting tumors are the most common adrenal tumors. They occur in elderly individuals with clinical signs of muscle weakness, hypokalemia and hypertension (DjajadiningratLaanen, 2011; Rossmeils et al., 2000).

In addition, tumors may occur in the adrenal medulla (i.e., the pheochromocytoma). They are generally malignant with metastasis rate of $40 \%$ in the lungs, liver, spleen, bone, central nervous system (Gillson, 1994). Around 82\% of them generate vascular invasion (Killes et al., 2003). In our case (Case 6), the clinical history didn't suggest a possible tumor in the adrenal medulla. The tumor was detected incidentally after necropsy. The main clinical symptoms that may occur in dogs with pheochromocytomas (often malignant) are: muscle weakness, recurrent collapse, anxiety, exercise intolerance, decreased appetite, weight loss, polyuria, polydipsia, cardiac arrhythmias, tachycardia, and hypertension (Herrera et al., 2010).

Endocrine thyroidal tumors were diagnosed in the cases 7 and 8 (Fig. 8). In one case a thyroidal tumor with follicular cells (Case 8; Fig. 8) was diagnosed, whereas the other dog showed thyroidal tumor with parafollicular cells (case 7). The clinical history didn't suggest their existence. Concerning the clinical signs, they may include the following: tachycardia, dyspnea, dysphagia, dysphonia, laryngeal paralysis, Horner syndrome and facial edema. In some dogs with hyperthyroidism the following symptoms may also occur: polyphagia, weakening, muscle weakness, polyuria and polydipsia (Feldman et al., 2004; Bezzola et al., 2002).

Parathyroid glands tumors are very rare. In the presented study, we diagnosed a bilateral hyperplasia of parathyroid glands (case 8). The latter aspect was rarely described in human endocrine pathology and even less in animal pathology. The hyperplasia or benign tumors of the parathyroid glands may provoke paraneoplastic syndromes that may be useful to establish the diagnosis (e.g., hypercalcemia, polyuria, polydipsia, lethargy, loss of appetite, weight loss, vomiting, urinary tract infection; Argyle et al., 2008).

A particular condition occurred in one dog showing multiple endocrine tumors (Case 8). This condition, defined Multiple Endocrine
Neoplasia (MEN) syndrome was described in few species, such as: horse, dog, cat and ox (Sponenberg et al., 1983; De Cock, 1999; Berger et al., 1991; Walker et al., 2000). MEN is characterized by the presence of at least one endocrine tumor associated with another (or others) hyperplastic or tumoral endocrine lesion. The genetic substrate for this syndrome was suggested in humans and animals (i.e., autosomal dominant gene; Phay et al., 2000; Thakker, 2000). This is the first description of MEN in dogs in Romania. The investigated dog presented thyroidal carcinoma (right thyroid), thyroidal adenoma (left thyroid), and hyperplasia of both parathyroid glands (i.e., bilateral). Phay et al. (2000) describe several types of MEN in dogs (i.e., MEN-1, MEN-2, MEN$2 \mathrm{~b}$ ). In the present report we observed a mixed MEN (or, according to some authors, the MEN$2 b$ type).

However, MEN-like lesions were diagnosed in other two cases. A dog (Case 4) showed multiple endocrine lesions in testes, namely a testicular Sertoli cells tumor associated with hyperplasia of the interstitial Leydig gland. Another dog (Case 6) was diagnosed with multiple endocrine lesions in the adrenal gland. Accordingly, a benign pheochromocytoma and hyperplastic lesions in the adrenal cortex (i.e., hyperplasia of the cortisol-dependent and aldosterone-dependent areas) were diagnosed in the Case no. 6. The presented cases could correspond to a MEN syndrome since some testicular tumors (Sertoli and Leydig cell tumors) are able to elaborate hormones (as shown above) (Morgan et al., 1982). The rarity of MEN-like syndromes makes this situation to be less investigated. The genetic involvement of MEN-like lesions remains to be demonstrated.

\section{CONCLUSION}

Endocrine tumors are extremely rare entities in animals. In most circumstances the clinical diagnosis is not easy; sometimes even the histological assessment is difficult to make a distinction between hyperplastic and neoplastic lesions. In subjects with endocrine disturbances, it is essential to investigate all endocrine glands in order to determine if the subject has or not the MEN or MEN-like syndromes. 


\section{REFERENCES}

1. Morgan R.V. (1982). Blood dyscrasias associated with testicular tumors in the dog. J Am Anim Hosp Assoc 18:970.

2. Baba A.I., Cătoi C. (2007). Comparative oncology. The Publishing House of Romanian Academy 533-567.

3. Brewer W.G.J., Crager C.S. (1991). A syndrome similar to multiple endocrine neoplasia type 1 in two dogs. Vet Cancer Soc Newslett 15:10-11.

4. Withrow S, Vail D., Page R. (2012). Small Animal Clinical Oncology. Ed. Saunders 504-531.

5. Walker MC, Jones B.R., Guildford W.G., Burbidge H.M., Alley M.R. (2000). Multiple endocrine neoplasia type 1 in a crossbreed dog. J. Small. Anim. Prac. 41:67.

6. Sponenberg DP, McEntee K. (1983). Pheochromocytomas and ultimobranchial (C-cell) neoplasms in the bull: evidence of autosomal dominant inheritance in the Guernsey breed. Vet. Pathol. 20:396-400.

7. Phay J.E., Moley J.F., Lairmore T.C. (2000). Multiple endocrine neoplasias. Semin Surg Oncol 18:324.

8. Thakker R.V. (2000). Multiple endocrine neoplasia type 1. Endocrinol Metab Clin North Am 29:541-567.

9. Lipowitz A.J., Schwartz A., Wilson G.P. (1973). Testicular neoplasms and concomitant clinical changes in the dog. J Am Vet Med Assoc 163:1364.

10. Brodey R.S., Martin J.E. (1958). Sertoli cell neoplasms in the dog: the clinicopathological and endocrinological findings in thirty-seven dogs. J Am Vet Med Assoc 133:249.

11. Reif J.S., T.G. Maguire, R.M. Kenney (1979). A cohort study of canine testicular neoplasia. J Am Vet Med Assoc 175:719.

12. Weaver AD (1983). Survey with follow-up of 67 dogs with testicular Sertoli cell tumours. Vet Rec 105:113.

13. von-Bomhard D, Pukkavesa C, Haenichen T (1978). The ultrastructure of testicular tumours in the dog: I. Germina cells and seminomas. J Comp Pathol 88:49.

14. Cotchin E. (1960). Testicular neoplasms in dogs. J Comp Pathol 70:232.

15. Liao A.T., Chu P.Y., Yeh L.S. (2009). A 12-year retrospective study of canine testicular tumors. Theriogenology 71:919.

16. Hayes H.M., Tarone R.E., Casey H.W. (1990). Excess of seminomas observed in Vietnam service U.S. military working dogs. J Natl Cancer Inst 82:1042.

17. Hayes H.M., Tarone R.E., Casey H.W. (1995). A cohort study of the effects of Vietnam service on testicular pathology of US military working dogs. Mil Med 160:248.
18. Reif J.S., Brodey R.S. (1969). The relationship between cryptorchidism and canine testicular neoplasia. J Am Vet Med Assoc 155:2005

19. Labelle P., Kyles A.E., Farver T.B. (2004). Indicators of malignancy of canine adrenocortical tumors: histopathology and proliferation index. Vet Pathol 41:490.

20. Feldman E.C., Nelson R.W. (2004). Hypercalcemia and primary hyperparathyroidism. In Canine and feline endocrinology and reproduction. Ed 3, Saunders, St. Louis.

21. Feldman, E.C., Nelson R.W. (2004). Canine hyperadrenocorticism (Cushing's syndrome). In Canine and feline endocrinology and reproduction. Ed 3, Saunders, St. Louis.

22. Feldman E.C., Nelson R.W. (2004). Gastrinoma, glucagonoma, and other APUDomas. In Canine and feline endocrinology and reproduction. Ed 3, Saunders, St. Louis.

23. Feldman, E.C., R.W. Nelson (2004). Pheochromocytoma and multiple endocrine neoplasia. In Canine and feline endocrinology and reproduction. Ed 3, Saunders, St. Louis.

24. Rossmeisl J.H. Jr., Scott-Moncrieff J.C., Siems J. (2000). Hyperadrenocorticism and hyperprogesteronemia in a cat with an adrenocortical adenocarcinoma. J Am Anim Hosp Assoc 36:512-517.

25. Djajadiningrat-Laanen S., Galac S., Kooistra H. (2011). Primary hyperaldosteronism: expanding the diagnostic net. J Feline Med Surg 13:641-650.

26. Gilson S.D., Withrow S.J., Wheeler S.L. (1994). Pheochromocytoma in 50 dogs. J Vet Intern Med 8:228-232.

27. Kyles A.E., Feldman E.C., De Cock H.E. (2003). Surgical management of adrenal gland tumors with and without associated tumor thrombi in dogs: 40 cases (1994-2001). J Am Vet Med Assoc 223:654-66.

28. Herrera M., Nelson R.W. (2010). Pheochromocytoma. In Ettinger SJ, Feldman EC, editors: Textbook of veterinary internal medicine. Ed. 7, Saunders Elsevier, St. Louis.

29. Bezzola P. (2002). Thyroid carcinoma and hyperthyroidism in a dog. Can Vet J 43:125-126.

30. Argyle J.D., Brearley M.J., Michelle M. Turek (2008). Decision Making in Small Animal Oncology. Ed. WileyBlackwell, Iowa, 3:390.

31. De Cock H.E.V., MacLachlan J. (1999). Simultaneous occurrence of multiple neoplasms and hyperplasias in the adrenal and thyroid gland of the horse resembling multiple endocrine neoplasia syndrome: case report and retrospective identification of additional cases. Vet Pathol 36:633.

32. Berger B., E.C. Feldman (1991). Primary hyperparathyroidism in dogs: six cases. JAVMA (191)56:350. 